\title{
Nearshore Wave Energy Assessment of Iranian Coastlines
}

\author{
M. Majidi Nezhad, D. Groppi, G. Piras \\ Department of Astronautics, Electrical and Energy Engineering (DIAEE), Sapienza University of Rome \\ Rome, Italy \\ meysam.majidinezhad@uniroma1.it; daniele.groppi@uniroma1.it; giuseppe.piras@uniroma1.it
}

\begin{abstract}
In this study, the measured wave data for year 2010 at 3 hour time step for six sites in the Caspian sea, Persian Gulf and Oman Sea of Iran have been statistically analysed to determine the wave power potential of Iranian coastlines. The statistical attitudes allows to estimate the significant weight height $\left(\mathrm{H}_{\mathrm{s}}\right)$, peak wave energy period $\left(\mathrm{T}_{\mathrm{p}}\right)$, and the wave energy flux for unit of crest length. This preliminary research aims to assess the nearshore wave energy potential and ultimately identify the best Wave Energy Converters (WECs) technology for the peculiar wave climate of the studied areas. Results show that wave power in Qeshm, Chabahar and Anzali presents the best potential and thus are the most indicated to be studied further the installation of Wave Energy Converters.
\end{abstract}

Keywords: Renewable Energy, Wave energy, Wave power, Wave Energy Converters (WEC).

\section{Introduction}

Nowadays, environmental concerns and the growing energy demand urge humankind to find renewable sources of energy in alternative to current options [1]. Global energy demand is expected to increase around 35\% from 2010 to 2040 [2]. Thus, on one hand the number of researches about coastal and marine areas risk assessment [3-4], oil spill detection [59] biodiversity vulnerability [10] hazardous and noxious substances risk assessment [11] is ever increasing; on the other hand a transition to alternative, low-carbon and Renewable Energy Sources (RES) is now a fact [12-17] even if fossil fuels still cover about the $80 \%$ of the total primary energy consumption [18] In this context, wind and solar energy have assumed a leading role [19] while exploitation of wave energy became one of the most challenging technological issues [20]. The worldwide theoretical wave power potential has been calculated as 29,500 TWh/y [21].

Iran is not an exception, the air above its territories is amongst the most polluted in the world, particularly in terms of PM2.5 concentrations that is the most harmful air pollutant for human health [22]. These days, Iranian government started research on renewable energies especially marine green energies given the long coastlines of the country. In fact, Iran shoreline overlooks the Caspian sea in the north, Persian Gulf and Oman sea in the south. The Persian Gulf is the third largest bay in the world and runs from the east through the Strait of Hormuz and the Oman Sea to the Indian Ocean and the Persian Gulf. The Caspian Sea is considered to be the largest lake in the world, it is interested by significant changes in water levels [23]. In Caspian Sea, the water depth in the south and west sides in Iran is high, therefore Caspian Sea presents a high potential to convert waves energy into electricity by means of WECs [24]. The high potential of Caspian Sea has been evaluated and described in [25] where its level and wave height variations have been analysed. The wave energy in a coastal location is very important for extracting energy but it has to be considered the WECs technology that is more appropriate for the peculiar conditions usually encountered in that area [26]. Experimental tests show that increasing the water depth causes an increment on the WEC oscillation and of heave and pitch directions [27]. WECs technologies can be classified according to their depth and location [28]. Among those, they can be categorized as onshore, nearshore (water depths between 20-25m) and offshore (water depths over 25m) [29-34]. In recent times, researchers have made great contributions toward the assessment of wave energy potential for various seas in many regions and countries, based on the analysis of wave. Wave energy has been reviewed by a number of investigators including; Vicinanza [35], Alamian [27], Iuppa [34]. Considerable works have been undertaken on wave energy assessment in several areas of: Italy [35-36], Ireland [37], Portugal [20], France [38], USA [39], Romania [30], Canada [40].

The present work focuses on a detailed assessment of nearshore wave energy potential in the Caspian Sea, Persian Gulf and Oman Sea. In this study, the measured wave data (i.e. wave height and peak wave energy period ) relative to year 2010 at 3 hours trend for six point in the Iranian Coastlines have been statistically analysed to determine the wave power potential. 
The statistical attitudes allows to estimate the significant weight height $\left(\mathrm{H}_{\mathrm{s}}\right)$ and the peak wave energy period $\left(\mathrm{T}_{\mathrm{p}}\right)$. At the end, we suggested several converters for installation in those areas.

\section{Analysis of Wave Data}

The data set used for the simulation was developed by the Iranian National Center for Ocean Data (INCOD). INCOD has been established to provide useful services in the field of oceanographic data management for marine researchers and organizations. This portal is accessible through the following address: http://incod.inio.ac.ir, users can access metadata records, atlases and data catalogues through the portal. INCOD has to guarantee a very high standard of quality for all the data provided. In particular, INCOD needs to follow the Quality Management Framework that is imposed to all the National Oceanographic Data Centers (NODCs), it provides strategy and guidance to implement quality management systems to ensure the delivery of high quality data and services. It is noteworthy that out of more than 80 NODCs in the World, just 4 countries have been awarded with the diploma of International Oceanographic Data Information Programme and INCOD is one of them. In particular regarding significant wave height and mean wave period, INCOD uses the GTDHZZ01 and the WVST standard respectively.

The data had a three hours time step and covered one year, from 01/01/2010 - 31/12/2010. The data obtained were the significant weight wave height $\left(\mathrm{H}_{\mathrm{s}}\right)$ and the peak wave energy period $\left(\mathrm{T}_{\mathrm{p}}\right)$ for six case study areas in the Caspian sea, Persian Gulf and Oman Sea. Fig. 1 shows the position of the six study areas (points Amirabad HS 1, Anzali HS 2, Noshaher HS 3 in Caspina Sea, point Chabahar HS 4 in Oman Sea and points Kish HS 5 and Qeshm HS 6 in Persian Gulf) and in Table 1, the data relative to the considered locations are shown.

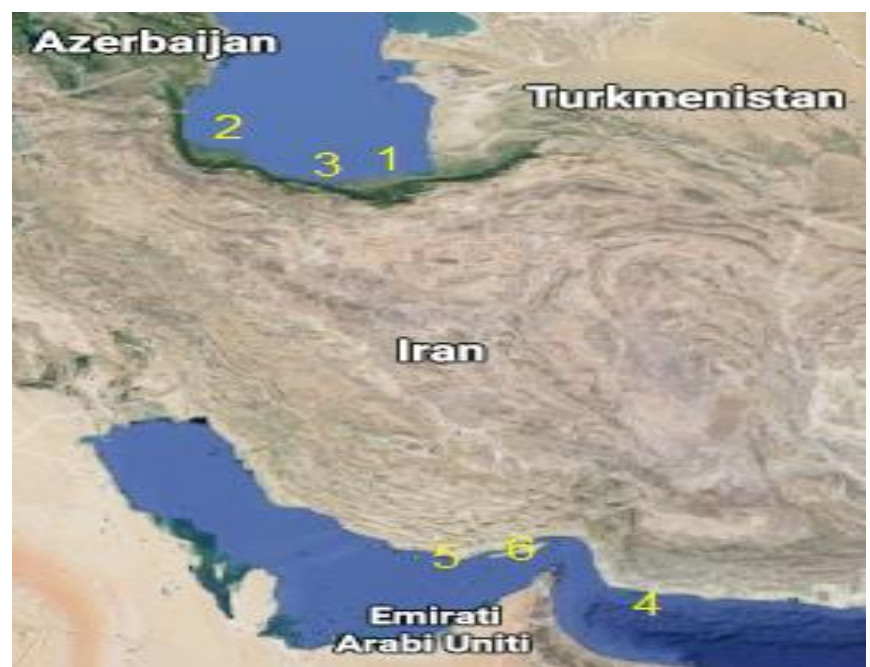

Fig. 1: Map points of study in this paper (Yellow Numbers).

Table 1: points study of Caspian Sea, Persian Gulf and Oman Sea details.

\begin{tabular}{|cccccc|}
\hline Point & Site & $\begin{array}{c}\text { Depth } \\
(\mathrm{m})\end{array}$ & $\begin{array}{c}\text { Distance } \\
\text { from coast } \\
(\mathrm{m})\end{array}$ & Lat $\left[{ }^{\circ}\right]$ & Lon $\left[{ }^{\circ}\right]$ \\
\hline 1 & Amirabad HS & 25 & 550 & 36.9343 & 53.3277 \\
\hline 2 & Anzali HS & 25 & 300 & 37.4893 & 49.4822 \\
\hline 3 & Noshaher HS & 25 & 220 & 36.6974 & 51.4692 \\
\hline 4 & Chabahar HS & 26 & 400 & 25.2635 & 60.6259 \\
\hline 5 & Kish HS & 23 & 550 & 26.4931 & 53.9853 \\
\hline 6 & Qeshm HS & 26 & 500 & 26.7697 & 56.0827 \\
\hline
\end{tabular}




\section{Results}

\section{1. $H_{s}$ and $T_{p}$}

In the first phase of the study, as shown in Figs 2-7, annual wave $H_{s}$ and $T_{p}$ with a time step of 3 hours for six different site have been examined i.e. Amir Abad, Anzali, Noshaher, Chabahar, Kish, Qeshm. The present work focuses on a detailed assessment of wave energy potential in Iran.

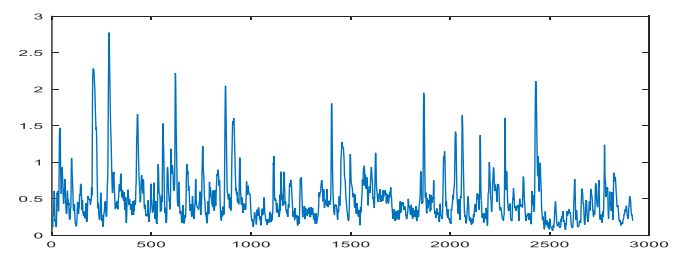

(a)

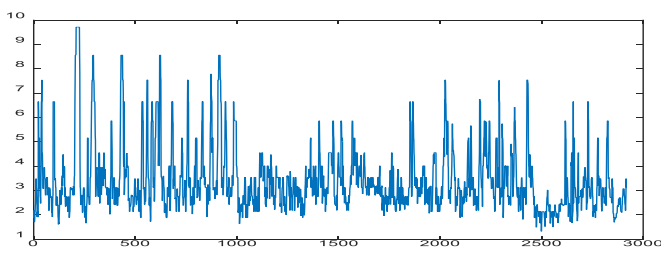

(b)

Fig. 2: Amirabad HS 1 significant hourly wave height $\mathrm{H}_{\mathrm{s}}$ in (a) and significant hourly wave energy period $\mathrm{T}_{\mathrm{p}}$ in (b).

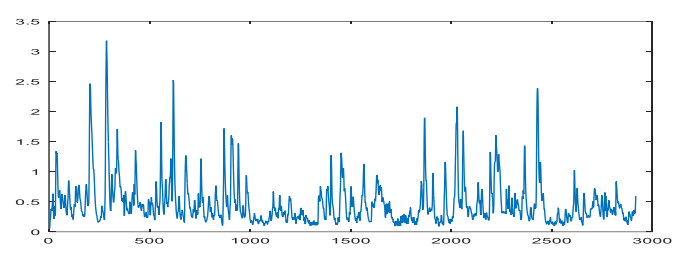

(a)

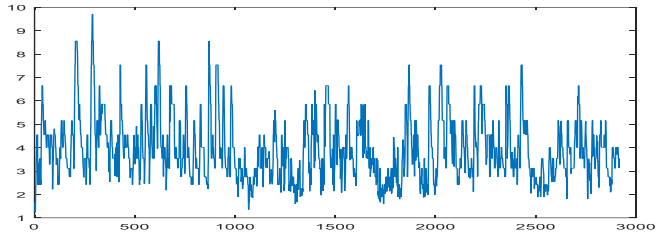

(b)

Fig. 3: Anzali HS 2 significant hourly wave height $H_{s}$ in (a) and significant hourly wave energy period $T_{p}$ in (b).

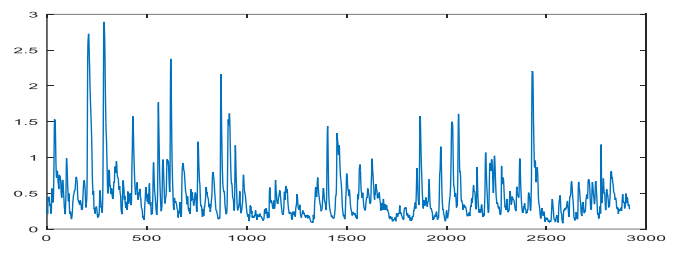

(a)

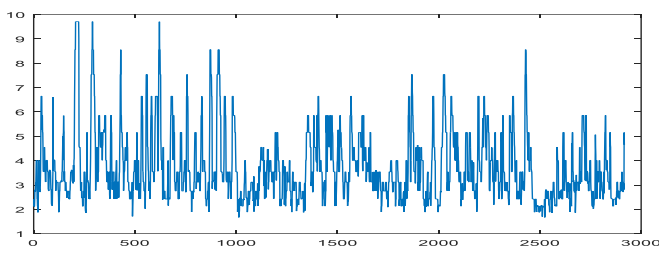

(b)

Fig. 4: Noshaher HS 3 significant hourly wave height $H_{s}$ in (a) and significant hourly wave energy period $T_{p}$ in (b).

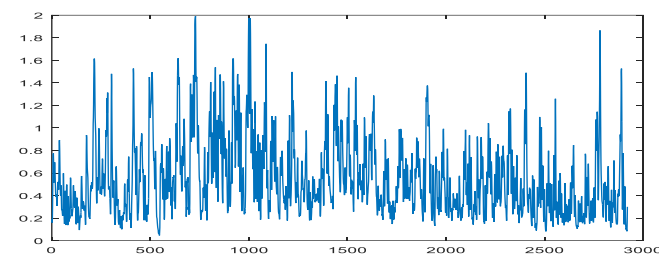

(a)

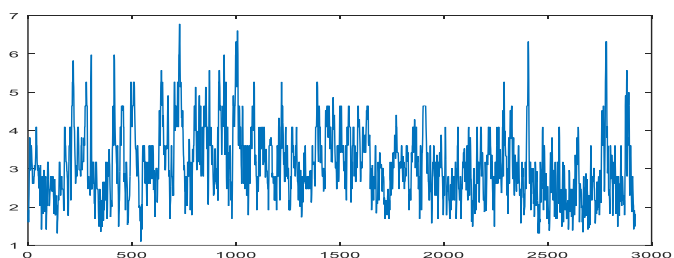

(b)

Fig. 5: Chabahar HS 4 significant hourly wave height $H_{s}$ in (a) and significant hourly wave energy period $T_{p}$ in (b).

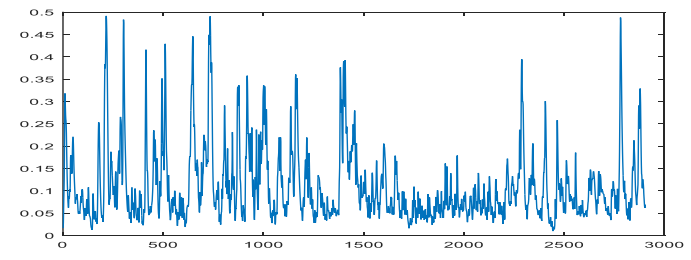

(a)

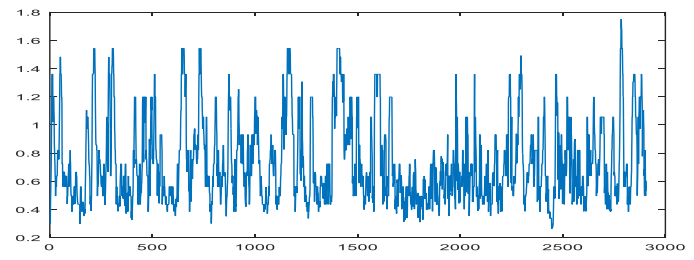

(b)

Fig. 6: Kish HS 5 significant hourly wave height $\mathrm{H}_{\mathrm{s}}$ in (a) and significant hourly wave energy period $\mathrm{T}_{\mathrm{p}}$ in (b). 


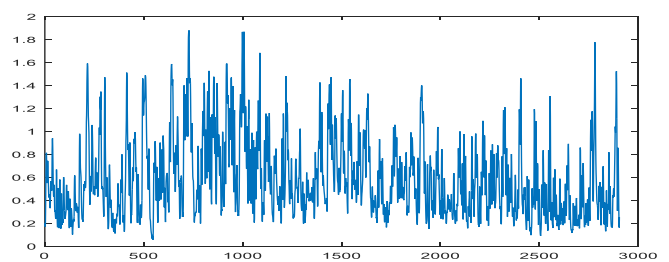

(a)

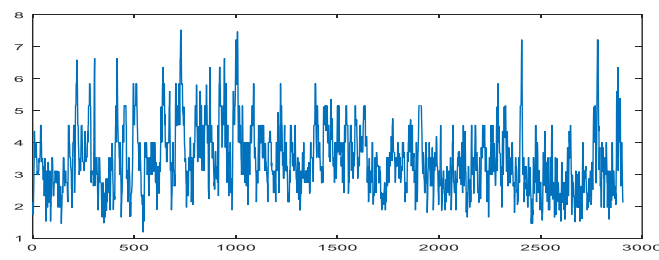

(b)

Fig. 7: Qeshm HS 6 significant hourly wave height $H_{s}$ in (a) and significant hourly wave energy period $T_{p}$ in (b).

Except for the site of Kish, all the other sites presents an average $H_{s}$ in the range of 0.46-0.59 m. Also regarding $T_{p}$ the sites have a similar behaviour. In fact, $T_{p}$ oscillates between a range of 2 to $8 \mathrm{~s}$ with the average values around 3.1-3.9 $\mathrm{s}$; the only exception is the Kish site that presents a maximum $T_{p}$ of $1.75 \mathrm{~s}$, a minimum of $0.26 \mathrm{~s}$ and an average peak wave energy period of $0.74 \mathrm{~s}$. Once the $\mathrm{H}_{\mathrm{s}}$ and the $\mathrm{T}_{\mathrm{p}}$ trends and average have been assessed the wave energy potential has to be evaluated.

\subsection{Wave Energy Potential}

The wave power exploitable from the Caspian Sea and Persian Gulf and Oman Sea has been estimated by means of Equation 1 [41][30][20];

$$
\mathrm{P}=\frac{1}{64 \pi} \rho g^{2} \mathrm{H}_{\mathrm{s}}^{2} T_{p}
$$

Where $\mathrm{H}_{\mathrm{s}}$ is the significant wave height (m), $\mathrm{T}_{\mathrm{p}}$ is the wave period (s), and $\mathrm{P}$ is the wave energy flux per unit of wave-crest length (W/m). Substituting $\rho=1000 \mathrm{~kg} / \mathrm{m}^{2}$ and $\mathrm{g}=9.81 \mathrm{~m} / \mathrm{s}^{2}$ in the above equation, the power can be calculatedas follows:

$$
\mathrm{P}=479 \mathrm{H}_{\mathrm{s}}^{2} \mathrm{~T}_{p}
$$

Fig 8 depicts the monthly power determined by measured data for the six study areas.

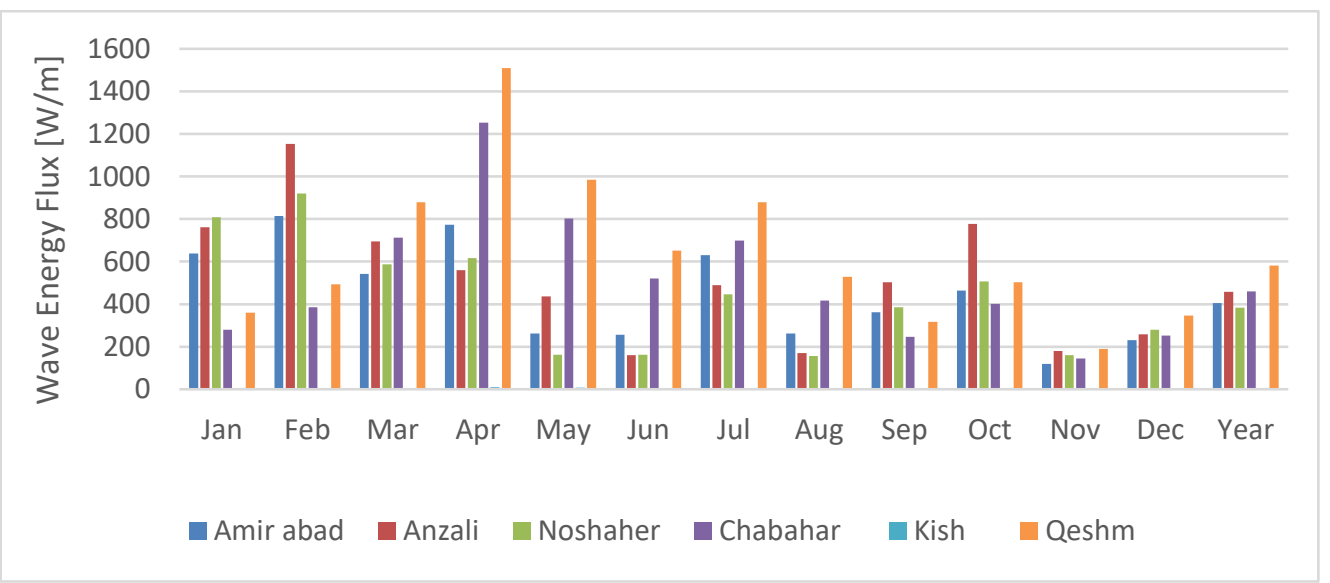

Fig. 8: Monthly wave energy flux per unit of crest length in year 2010 (W/m).

In Fig 8, the assessment of the monthly and yearly mean wave power has been summarised. The extent to which extracting energy from waves represents a realistic opportunity is concluded by economic considerations that have to account for site specific characteristics such as sea bottom surface typology and distance from the electric grid or from the energy load. As preliminary analysis, in this study the most suitable site for wave energy exploitation have been identified considering exclusively wave energy fluxes. Hence, the most suitable site is Qeshm, it presents an wave energy flux per crest 
length of almost $600 \mathrm{~W} / \mathrm{m}$. It is followed by the sites of Anzali and Chabahar that have a wave energy flux of almost 500 $\mathrm{W} / \mathrm{m}$.

In order to envisage potential location for WECs in 6 points of this study, the power density of the study areas, according to $\mathrm{T}_{\mathrm{p}}$ and $\mathrm{H}_{\mathrm{s}}$ contour, was computed and it is shown in Fig 9-14. Combined scatter and energy diagrams have been created so as to illustrate the contribution of different sea states with different significant wave height and period to the annual wave energy. The most frequent sea states is an essential feature of the marine climate in order to identify the best WEC technology. In fact, WECs have different performance depending to $\mathrm{T}_{\mathrm{p}}$ and $\mathrm{H}_{\mathrm{s}}$.

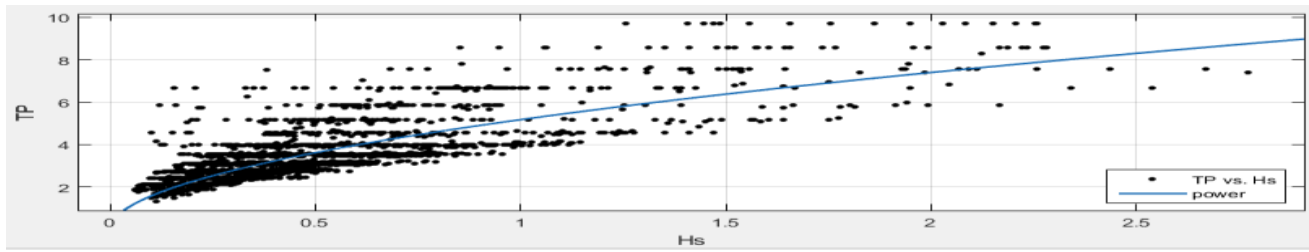

Fig. 9: Scatter plot Amirabad HS 1 wave power 2010.

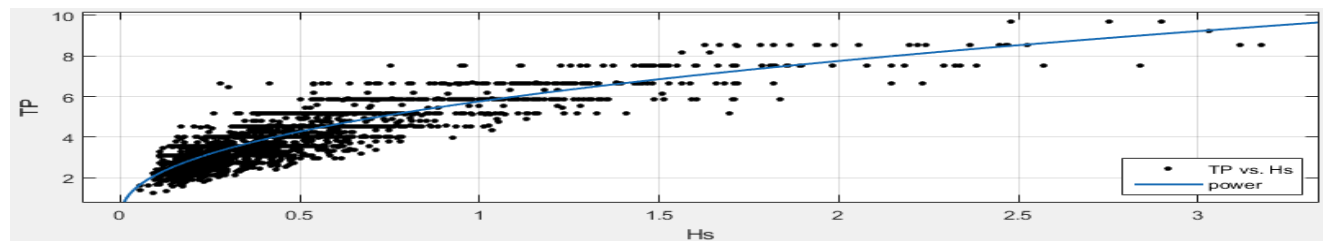

Fig. 10: Scatter plot Anzali HS 2 wave power 2010.

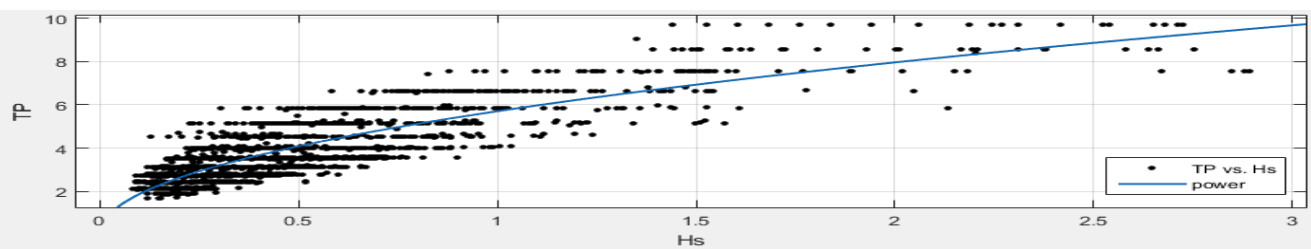

Fig. 11: Scatter plot Noshaher HS 3 wave power 2010.

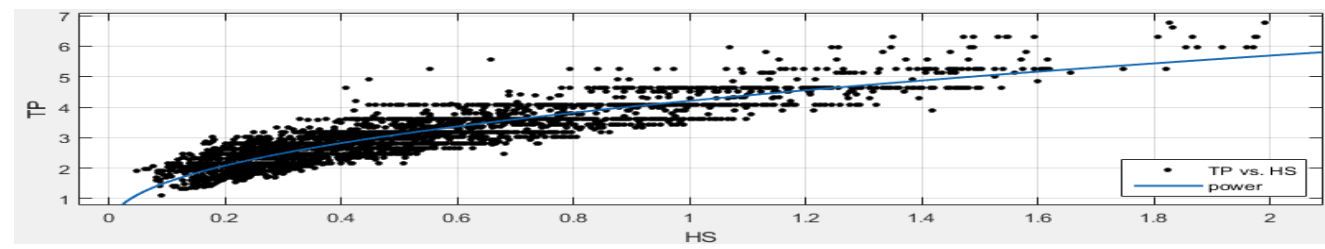

Fig. 12: Scatter plot Chabahar HS 4 wave power 2010.

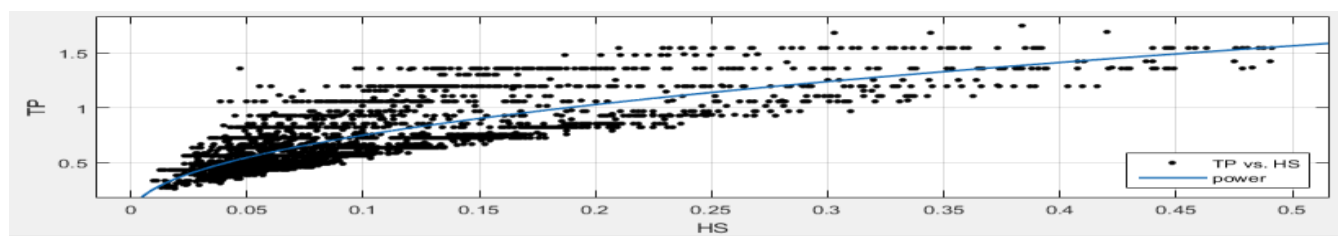

Fig. 13: Scatter plot Kish HS 5 wave power 2010. 


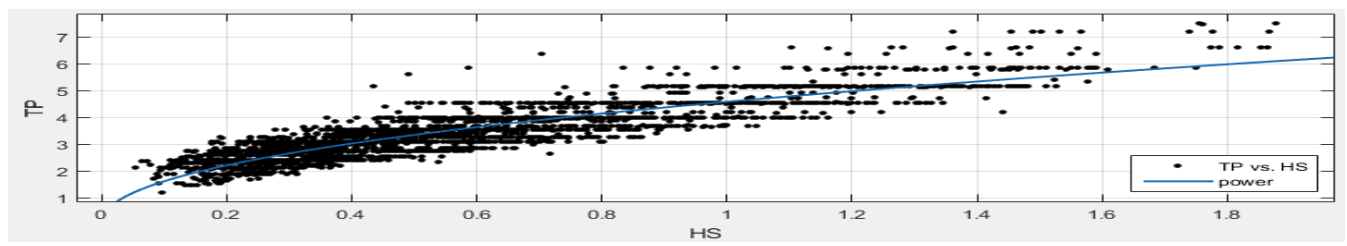

Fig. 14: Scatter plot Qeshem HS 6 wave power 2010.

Finally, some consideration about the best WEC technology for harvesting wave energy have been develoepd. In Table 2, the characteristics of three nearshore WEC technologies are shown. From this preliminary analysis, those WECs have been identified as the best technologies for the six study areas given the wave climate that is mainly characterised by wave with $H_{s}$ around $1 \mathrm{~m}$ and $T_{s}$ in a range between 2 and $6 \mathrm{~s}$.

Table 2. The characteristics of WECs device [42-43].

\begin{tabular}{|c|c|c|c|c|c|}
\hline WECs & $\begin{array}{c}\text { Water depth } \\
(\mathrm{m})\end{array}$ & $\begin{array}{c}\text { Mean wave power } \\
(\mathrm{kW} / \mathrm{m})\end{array}$ & $\begin{array}{c}\text { Output power } \\
(\mathrm{kW})\end{array}$ & $\begin{array}{c}\text { Generator } \\
\text { position }\end{array}$ & Photograph \\
\hline $\begin{array}{c}\text { Wave } \\
\text { Dragon }\end{array}$ & $20-30$ & 24 & 40 & In water \\
\hline Wave Star & $2-30$ & 24 & $500-6000$ & $\begin{array}{c}\text { Over water } \\
\text { surface }\end{array}$ \\
\hline Oyster & $25-40$ & $35-50$ & 250 & Fixed Bottom \\
\hline
\end{tabular}

In this work, the total wave power was used because our first aim was to describe the energy flux due to wave propagation. To establish the fraction of extractable resource, more detailed considerations about wave energy conversion technologies were required. It is expected that, depending on the selected site characteristics, some technologies could be more efficiently used than others. In any case, the selection of the optimal capturing scheme is a complex matter which cannot be done in a preliminary analysis.

\section{Conclusion}

In this study, one year wave data (2010) with a three hour time step provided by INCOD have been analysed. A preliminary study of 6 different sites in the Caspian sea, Persian Gulf and Oman sea has been presented. This work aims at preliminary assessing wave energy potential around Iranian coastlines and identify potential locations for use WECs, such results have to be considered exclusively as a first step of the analysis, and detailed examination and feasibility analysis are required. Hence, the most important parameters to determine a wave climate about six locations that are representatives for Caspian Sea, Persian Gulf and Oman Sea are described. Results obtained show that the wave energy potential is low in all the nearshore locations that have been studied. The most interesting sites, whose potential justify further investigation are Qeshm, Anzali and Chabahar with an energy flux per unit of crest length range between 500-600 W/m. Some WECs nearshore technologies have been suggested. According to the site-specific wave climate that is characterised by a low $\mathrm{H}_{\mathrm{s}}$ (i.e. in the range of 0.46-0.59 m) and an average period between 3.1-3.9 s, the specific design of new WEC technologies should performed according to the mentioned wave characteristics.

\section{References}

[1] P. Beir and D. Val, "Thermal modelling of the Archimedes Wave Swing," Isope, no. July 2007, pp. 513-520, 2007.

[2] D. Vicinanza, P. Contestabile, J. Quvang Harck Nrgaard, and T. Lykke Andersen, "Innovative rubble mound 
breakwaters for overtopping wave energy conversion," Coast. Eng., vol. 88, pp. 154-170, 2014.

[3] M. Marignani et al., "Identification and prioritization of areas with high environmental risk in Mediterranean coastal areas: A flexible approach,” Sci. Total Environ., vol. 590-591, no. May, pp. 566-578, 2017.

[4] L. De Santoli, F. Cumo, D. Astiaso Garcia, and D. Bruschi, "Coastal and marine impact assessment for the development of an oil spill contingency plan: The case study of the east coast of Sicily," WIT Trans. Ecol. Environ., vol. 149, pp. 285-296, 2011.

[5] F. Gugliermetti, F. Cinquepalmi, and D. Astiaso Garcia, "The use of environmental sensitivity indices (ESI) maps for the evaluation of oil spill risk in Mediterranean coastlines and coastal waters," WIT Trans. Ecol. Environ., vol. 102, pp. 593-600, 2007.

[6] A. Al Shami, G. Harik, I. Alameddine, D. Bruschi, D. A. Garcia, and M. El-Fadel, "Risk assessment of oil spills along the Mediterranean coast: A sensitivity analysis of the choice of hazard quantification," Sci. Total Environ., vol. 574, pp. 234-245, 2017.

[7] D. Astiaso Garcia, D. Bruschi, F. Cumo, and F. Gugliermetti, "The Oil Spill Hazard Index (OSHI) elaboration. An oil spill hazard assessment concerning Italian hydrocarbons maritime traffic," Ocean Coast. Manag., vol. 80, pp. 1-11, 2013.

[8] F. Cumo, F. Cinquepalmi, and D. Astiaso Garcia, "Data gathering guidelines for the mapping of environmental sensitivity to oil spill of the Italian coastlines," WIT Trans. Built Environ., vol. 99, pp. 119-125, 2008.

[9] M. M. Nezhad, D. Groppi, G. Laneve, P. Marzialetti, and G. Piras, "Oil Spill Detection Analyzing ' Sentinel 2' Satellite Images A Persian Gulf Case Study,” pp. 1-8, 2018. DOI: 10.11159/awspt18.134.

[10] G. Harik et al., "Implications of adopting a biodiversity-based vulnerability index versus a shoreline environmental sensitivity index on management and policy planning along coastal areas," J. Environ. Manage., vol. 187, pp. 187200, 2017.

[11] D. Astiaso Garcia, F. Cumo, F. Gugliermetti, and F. Rosa, "Hazardous and noxious substances (HNS) risk assessment along the italian coastline," Chem. Eng. Trans., vol. 32, pp. 115-120, 2013.

[12] G. Lo Basso, B. Nastasi, F. Salata, and I. Golasi, "Energy retrofitting of residential buildings - How to couple Combined Heat and Power (CHP) and Heat Pump (HP) for thermal management and off-design operation," Energy Build., vol. 151, no. July, pp. 293-305, 2017.

[13] L. De Santoli, F. Mancini, B. Nastasi, and S. Ridolfi, "Energy retrofitting of dwellings from the 40's in Borgata Trullo -Rome," Energy Procedia, vol. 133, pp. 281-289, 2017.

[14] B. Castellani et al., "Experimental investigation on CO2 methanation process for solar energy storage compared to CO2-based methanol synthesis," Energies, vol. 10, no. 7, pp. 1-13, 2017.

[15] M. Noussan and B. Nastasi, "Data Analysis of Heating Systems for Buildings-A Tool for Energy Planning, Policies and Systems Simulation," Energies, vol. 11, no. 2, p. 233, 2018.

[16] L. De Santoli, G. Lo Basso, and B. Nastasi, "Innovative Hybrid CHP systems for high temperature heating plant in existing buildings," Energy Procedia, vol. 133, pp. 207-218, 2017.

[17] M. Noussan, R. Roberto, and B. Nastasi, "Performance Indicators of Electricity Generation at Country Level—The Case of Italy," Energies, vol. 11, no. 3, p. 650, 2018.

[18] F. Calise, M. D. D’Accadia, C. Barletta, V. Battaglia, A. Pfeifer, and N. Duic, "Detailed modelling of the deep decarbonisation scenarios with demand response technologies in the heating and cooling sector: A case study for Italy," Energies, vol. 10, no. 10, 2017.

[19] Dominković, D. F., Bačeković, I., Ćosić, B., Krajačić, G., Pukšec, T., Duić, N. ,Markovska, N., “Zero carbon energy system of South East Europe in 2050," Appl. Energy, vol. 184, pp. 1517-1528, 2016.

[20] D. Silva, E. Rusu, and C. G. Soares, "Evaluation of various technologies for wave energy conversion in the portuguese nearshore," Energies, vol. 6, no. 3, pp. 1344-1364, 2013.

[21] J. Huckerby, H. Jeffrey, J. Sedgwick, B. Jay, and L. Finlay, "An international vision for Ocean energy- version II," Ocean Energy Syst. Implement. Agreem., 2012.

[22] T. Reintegration, "Iran Economic Monitor Towards Reintegration," 2016.

[23] Vladimir Mamaev, "The Caspian Sea," Eur. Environ. Agency, p. 259, 1994.

[24] J. Faiz and M. Ebrahimi-salari, "Wave Power Resource in Iran for Electrical Power Generation," World Renew. Energy Congr. 8-13 May; 2011; Linköping; Sweden, no. 57, pp. 3412-3419, 2011. 
[25] S. A. Lebedev and A. G. Kostianoy, "Satellite altimetry of the Caspian Sea," pp. 113-120, 2004.

[26] E. Rusu, "Evaluation of the Wave Energy Conversion Efficiency in Various Coastal Environments †," pp. 4002-4018, 2014.

[27] R. Alamian, R. Shafaghat, M. S. Shadloo, R. Bayani, and A. H. Amouei, "An empirical evaluation of the sea depth effects for various wave characteristics on the performance of a point absorber wave energy converter," Ocean Eng., vol. 137, no. June, pp. 13-21, 2017.

[28] SETIS, “Ocean Energy: Technology Information Sheet," 2014.

[29] A. F. de O. Falca and o, "Wave energy utilization: A review of the technologies," Renew. Sustain. Energy Rev., vol. 14, no. 3, pp. 899-918, 2010.

[30] S. Diaconu and E. Rusu, "Evaluation of various WEC devices in the Romanian near shore 2 Wave climate in the western Black Sea 3 Conversion of the Wave Energy into Electrical Energy."

[31] J. Falnes, "A review of wave-energy extraction," Mar. Struct., vol. 20, no. 4, pp. 185-201, 2007.

[32] C. Bosserelle, S. Reddy, and J. Krüger, Waves and Coasts in the Pacific: Cost analysis of wave energy in the Pacific. 2015.

[33] A. Vosough, "Wave Energy,” Int. J. Multidiscip. Sci. Eng., vol. 2, no. 7, pp. 60-63, 2011.

[34] C. Iuppa, L. Cavallaro, E. Foti, and D. Vicinanza, "Potential wave energy production by different wave energy converters around Sicily," J. Renew. Sustain. Energy, vol. 7, no. 6, 2015.

[35] D. Vicinanza, P. Contestabile, and V. Ferrante, "Wave energy potential in the north-west of Sardinia (Italy)," Renew. Energy, vol. 50, pp. 506-521, 2013.

[36] C. Iuppa, L. Cavallaro, D. Vicinanza, and E. Foti, "Investigation of suitable sites for wave energy converters around Sicily (Italy)," Ocean Sci., vol. 11, no. 4, pp. 543-557, 2015.

[37] S. Gallagher, R. Tiron, E. Whelan, E. Gleeson, F. Dias, and R. McGrath, "The nearshore wind and wave energy potential of Ireland: A high resolution assessment of availability and accessibility," Renew. Energy, vol. 88, pp. 494516,2016

[38] A. Clément et al., "Wave energy in Europe: Current status and perspectives," Renew. Sustain. Energy Rev., vol. 6, no. 5, pp. 405-431, 2002.

[39] J. Klure, K. Dragoon, J, King, G. Reikard, "Wave Energy Utility Integration Wave Integration Project," 2013.

[40] G. Reikard, B. Robertson, B. Buckham, J.-R. Bidlot, and C. Hiles, "Simulating and forecasting ocean wave energy in western Canada," Ocean Eng., vol. 103, pp. 223-236, 2015.

[41] R. Alamian, R. Shafaghat, S. J. Miri, and N. Yazdanshenas, "Evaluation of technologies for harvesting wave energy in Caspian Sea," Renew. Sustain. Energy Rev., vol. 32, pp. 468-476, 2014.

[42] M. A. Mustapa, O. B. Yaakob, Y. M. Ahmed, C. K. Rheem, K. K. Koh, and F. A. Adnan, "Wave energy device and breakwater integration: A review," Renew. Sustain. Energy Rev., vol. 77, no. September, pp. 43-58, 2017.

[43] P. Frigaard, J. P. Kofoed, and W. Knapp, "Wave Dragon. Wave Power Plant using low-head turbines," vol. 2004, 2004. 